\begin{tabular}{|l|l|}
\hline $\begin{array}{l}\text { 2. To: (Receiving Organization) } \\
\text { Facility Modification }\end{array}$ & $\begin{array}{l}\text { 3. From: (Originating Organization) } \\
\text { Facility Cleanup Projects }\end{array}$ \\
\hline 5. Proj./Prog./Dept./Div.: & $\begin{array}{l}\text { 6. Design Authority/ Design Agent/Cog. } \\
\text { Engr.: }\end{array}$ \\
Spent Nuclear Fuel Project & D. R. Precechtel \\
\hline
\end{tabular}

8. Originator Remarks:

Issued for review and approval and release

11. Receiver Remarks:

11A. Design Basel ine Document?

[] Yes

$[x]$ No

\section{Related EDT No.: \\ N/A \\ 7. Purchase Order No.: \\ $\mathrm{N} / \mathrm{A}$}

9. Equip./Component No.:

$\mathrm{N} / \mathrm{A}$

10. System/Bldg./Facility:

$105 \mathrm{~K}$ Basins

12. Major Assm. Dwg. No.:

$N / A$

13. Permit/Permit Application No.: $\mathrm{N} / \mathrm{A}$

14. Required Response Date: $3 / 18 / 97$

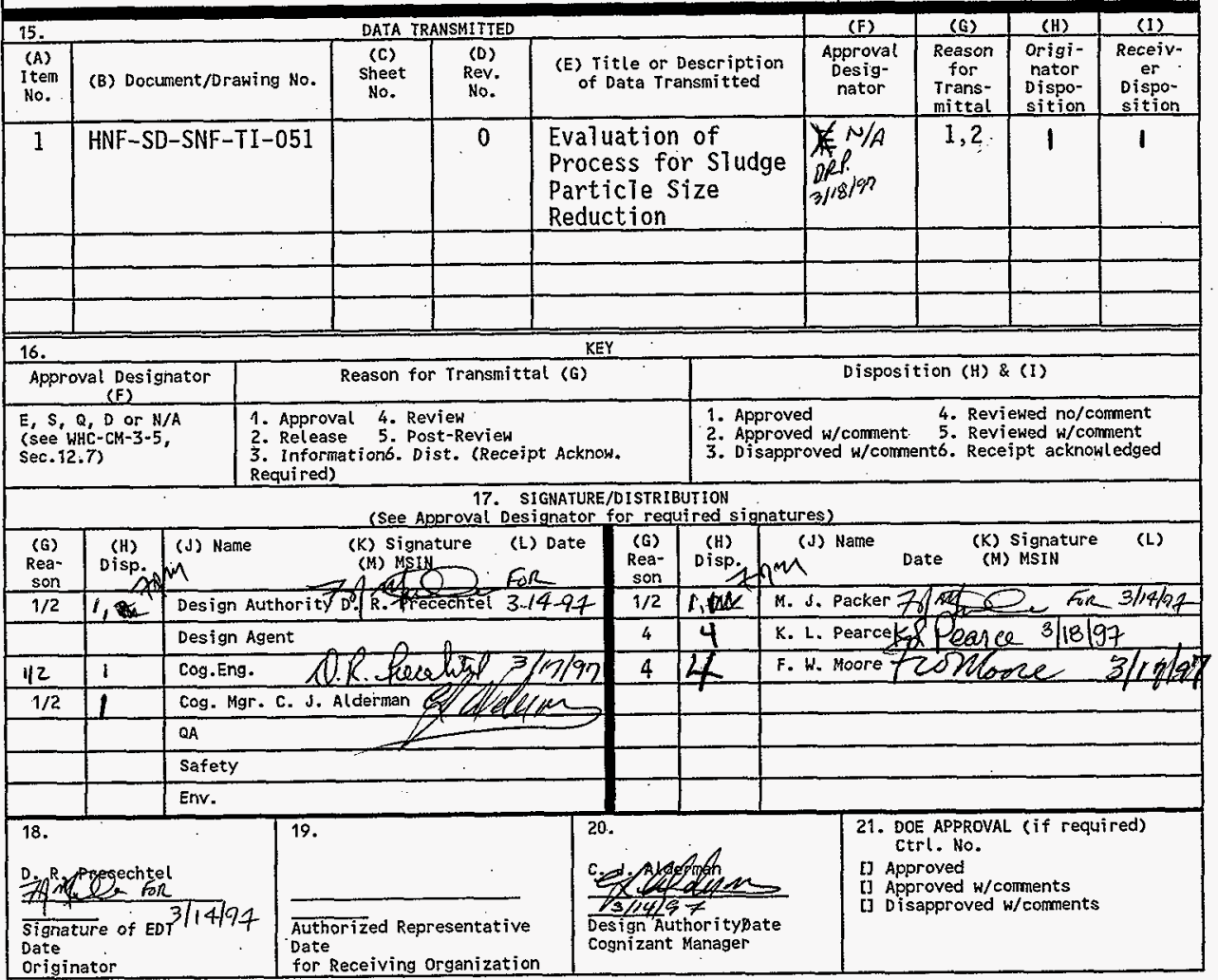

BD-7400-172-2 (05/96) GEF097 


\title{
Evaluation of Process for Sludge Particle Size Reduction
}

\author{
D. R. Precechtel/M. J. Packer
}

Duke Engineering and Services Hanford, Inc., Richland, WA 99352

U.S. Department of Energy Contract DE-AC06-96RL13200

$\begin{array}{lll}\text { EDT/ECN: } & 619695 & \text { UC: } 600 \\ \text { Org Code: } & 2 \text { T240 } & \text { Charge Code: } \\ \text { B\&R Code: } & \text { EW } 3135040 & \text { Total Pages: } 8\end{array}$

Key Words: K East Basin, Sludge, Particle Size Reduction

Abstract: This document evaluates the available technology for $\mathrm{K}$ Basin sludge particle size. The results can be used to demonstrate the sensitivity or lack thereof, of $K$ Basin sludge to available reduction processes and TWRS proposed particle acceptance criteria.

TRADEMARK DISCLAIMER. Reference herein to any specific comnercial product, process, or service by trade name, trademark, manufacturer, or otherwise, does not necessarily constitute or imply its endorsement, recommendation, or favoring by the United States Government or any agency thereof or its contractors or subcontractors.

Printed in the United states of America. To obtain copies of this document, contact: Document Control Services, P.0. Box 950, Mailstop H6-08, Richland WA 99352, Phone (509) 372-2420;

Fax (509) 376-4989.

*uis Bradon RBtease Approval $\frac{3 / 18197}{\text { Date }}$

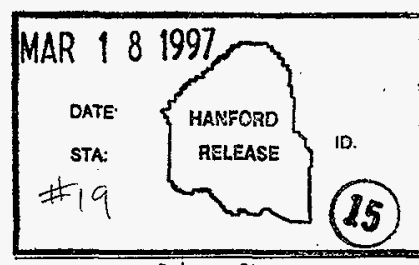

Release Stamp

\section{Approved for Public Release}


HNF-SD-SNF-TI-051，Rev. 0

EVALUATION OF PROCESSES FOR SLUDGE PARTICLE SIZE REDUCTION

\subsection{INTRODUCTION}

The Hanford Tank Waste Remediation System (TWRS) performed a waste compatibility assessment for mixing $105-\mathrm{K}$ East Basin floor and pit sludge with Tank 241-AW-105 waste. As a result of this assessment, an analysis was completed to establish an acceptable particle size range for acceptance of $\mathrm{K}$ Basin sludge into the double-shell tank (DST) system. The analysis discusses the impact that large particles would have on criticality safety, waste retrieval, and vitrification technology. The analysis concluded that the limiting basis for maximum acceptable particle size is driven by limitations of vitrification technology (Boston 1997). Based on conclusions of this analysis, a particle size limit of less than $177 \mu \mathrm{m}$ diameter has been recommended for acceptance of $\mathrm{k}$ Basin sludge into the DST system.

\subsection{SCORE OF REPORT}

The purpose of this evaluation is to determine if private industry has available technology for reducing the $\mathrm{K}$ Basin sludge particle size. Included is a survey of both size reduction processes and equipment suppliers with the technology. The results can be used to demonstrate the sensitivity, of $k$ Basin sludge to available size reduction processes and TWRS proposed particle acceptance criteria.

The TWRS proposed particle size limit of 80 mesh (177 $\mu \mathrm{m}$ diameter) is used for the initial process acceptance criteria. Other particle sizes have been identified as potentially acceptable and will be evaluated. A $1,450 \mu \mathrm{m}$ ( 0.052 inch) particle size has been identified by TWRS in consideration of criticality issues. Based on $\mathrm{K}$ Basin sludge material characteristics and availability of industrial equipment, conclusions and a recommendation were established for a reasonably achievable particle size.

\subsection{BACKGROUND}

The 105-K East Basin currently stores spent nuclear fuel (SNF). sludge, and debris. The SNF is stored in open top aluminum and steel canisters. Over the years, deterioration of these canisters, the concrete basin walls, and SNF elements as well as infiltration of environmental contaminants such as dust, rodents, and insects, have left a buildup of contaminated sludge on the floor of the 105-K East Basin. Because the 105-K East Basin is located in close proximity to the Columbia River, it is desirable to remove this sludge in an attempt to reduce the safety hazards associated with potential leakage of the basin pool.

The SNF Project is currently planning activities to retrieve and remove sludge that continues to accumulate in the $\mathrm{K}$ Basins. Sludge retrieval will be accomplished using pumps and vacuum heads which include a strainer with $6400 \mu \mathrm{m}$ (0.25 inch) holes to prevent transfer of larger size particles to in-basin sludge storage areas. The SNF Project plans to transfer all particulate solids that are less than $6,400 \mu \mathrm{m}(0.25$ inch) in diameter to the TWRS.

However, the TWRS analysis identified that the $6,400 \mu \mathrm{m}(0.25$ inch) maximum particle size identified in the Sludge Removal System Functional Design Criteria (Precechtel 1996) will not be acceptable. This contraint identified the need for this survey and evaluation of equipment available in private industry for reducing the $\mathrm{K}$ Basin sludge particle size prior to transfer into the DST system was performed. 


\subsection{PARTICLE SIZE CHARACTERISTICS OF K BASIN SLUDGE}

Particle size determinations were made on two sludge samples retrieved from the $K$ East Basin floor. Each sample was subdivided into a "top" and "bottom" fraction for a total of four samples. The mean volume probability particle diameter for the $\mathrm{K}$ Basin sludge is approximately 20-30 $\mu \mathrm{m}$. The particles are distributed in a broad based "bell" curve with the lower end at $0.243 \mu \mathrm{m}$ and the upper end at 300-700 $\mu \mathrm{m}$. Information obtained from sludge characterization data to date is inadequate to establish the fraction of the sludge that is comprised of large particles. Due to limitations of analysis equipment, particle size data for particles that are between 700 m and 6400 $\mu \mathrm{m}$ is currently not available. The volume of particles greater than $700 \mu \mathrm{m}$ was not counted (Makenas, et al. 1996); therefore, ion exchange beads and incidental debris are not covered by this analysis. One sample has been described as consisting of up to 40-50 percent ion exchange beads.

Graduated cylinders were used to perform gravity settiing tests on twelve of the eighteen sludge samples. Nearly all samples exhibited stratified settling. Sludge densities vary widely, from $1.04 \mathrm{~g} / \mathrm{ml}$ to 2.28 $\mathrm{g} / \mathrm{ml}$. (Mekenas, et al. 1996)

Revised estimates of the sludge volumes in the $\mathrm{K}$ East and $\mathrm{K}$ West Basins indicate a total of $2.6 \mathrm{~m}^{3}$ to $6.4 \mathrm{~m}^{3}$ of metal fuel particles less than $6,400 \mu \mathrm{m}$ (0.25 inch) will be generated by the fuel cleaning station (Baker to Kathleen memo). This is important because any particle size reduction process would be less efficient when dealing with materials having a large hardness value.

Typical hardness values are reported for heat-treated uranium, before irradiation, of $368 \mathrm{DPH}$ and, after irradiation, of $440 \mathrm{DPH}$ (Tipton 1960). As a comparison, 316 stainless steel has a hardness value of 195 DPH and is used in size reduction machines for cutter or hammer blade material.

A reduction in impact strength by a factor of 3 to 4 is another characteristic of irradiated uranium (Konobeevsky 1956). This coupled with the increased hardness indicates that the irradiated uranium particles should be very brittle which should facilitate size reduction operations.

\subsection{DISCUSSION}

A literature and vendor search was initiated to determine viable physical; reduction methods available for $\mathrm{K}$ Basin sludge. Several methods and associated vendors were identified as possible candidates for the $K$ basin sludge particle reduction process. The identified vendors were further reduced to a selection of just five companies. These five vendors and their reduction methods are better defined and evaluated in this document.

\subsection{DESCRIPTION OF POTENTIAL OPTIONS}

Several equipment suppliers were found which manufacture size reduction equipment. The following include five selected suppliers, their product description, and principle of operation for their equipment.

A. PULVA CORP. - Hammer Mill - This is an impact-type grinding mill using hammers. A hammer mill can be used for a wide range of sizes, from course granulated products to very fine grinds. It can be used for wet and dry milling operations.

The principle of operation is the same in most models: a rotor having either swing hammers or fixed hammers within a grinding chamber. The upper half of the grinding chamber consists of an easily removable, hinged cover containing a replaceable liner.

It is possible to obtain very accurate control of particle size by supplying various types of liners in the cover and maintaining 
close clearance between the tops of the hammers and the cover liner.

The Pulva Corp. currently has customers who grind tungsten carbide; however, there is no information on the input size or grinding capabilities. Standard materials used include iron oxide, aluminum, and magnesium at production rates of $300-400$ lbs/hr. One drawback to this machine is the ability to clog if feed material is damp or pasty. A $30 \mathrm{v} / \mathrm{v} \%$ sludge feed material would probably pose no problem with clogging; however, no information was provided on the reduction efficiency with an aqueous slurry feed. Testing would be reguired with a sludge simulant to verify production rates and machine life cycle due to typical hardness values of uranium in the sludge stream.

b. HOSOKAWA MICRON POWER SYSTEMS - Hammer Mill - Hosokawa SYstems can provide hammer mill machines ranging from 5 to $125 \mathrm{hp}$. A $15 \mathrm{hp}$ machine is able to reduce relatively dry solids, such as carbon steel, at $45 \mathrm{gal} / \mathrm{min}$. to a particle size of $177 \mu \mathrm{m}$. An aqueous feed, such as the type expected from $\mathrm{K}$ basins sludge, would render the grinding capability less efficient. Reduction problems are expected with this system with use of an aqueous slurry feed. The vendor did not recommend their system for the $k$ basins application.

c. SHRED RAX SYSTEMS, INC - Shredder - The shred Pax shredder is an impact-type shredder system employing the use of hammer to shear industrial scrap, hazardous waste, pallets, tires, metals, glass, plastics, and other materials. It can be used for a wide range of sizes and is applied mostly in the waste volume reduction and product recovery systems. The shredder can be used for wet and dry process applications.

Operation of this type of machine is completed by discharging the feed material into a shredder chamber containing rotor type shear blades. The clearance between the blades determines the size reduction.

The Shred Pax shredder was utilized in the 300 Area fuel fabrication process area in the past to reduce scrap uranium to $6400 \mu \mathrm{m}(0.25 \mathrm{inch})$ pieces prior to a thermal oxidation process. There is no information available from the vendor regarding possible further reduction of the output size.

d. IKA WORKS, INC - Grinder/Dispersing - The IKA works system is a very high performance dispersing machine which employs the use of a rotor-stator and can be used to produce very fine particle sizes. The machines cover the complete field of dispersing technique that comprise the production of emulsions (Iiquid/liquid) and suspensions (liquid/solid).

The recommended machine was the Dispax Reactor model DR-3-13P. This is a three stage high sheer machine which contains three independent rotor stator pairs (also know as generators). These generators are designated coarse, medium, fine, or superfine. Therefore, particles can be progressively reduced in size as they pass through the machine. This configuration could be used to reduce any particle above 177 microns in size. Having three independent generators in series greatly increases the probability for a one pass operation.

e: GLEN MILLS, INC - Toothed DHC Mill Grinder - Grinding takes place between stationary and rotating corundum discs whose teeth are arranged in concentric intermeshing rings. The inner teeth are rugged and large, acting as primary crushers. The central and outer rows of teeth are gradually smaller and more numerous, giving a progressively finer grinding effect. 
HNF-SD-SNF-TI-051, Rev. 0

Tests will be required with a selected sludge simulant to determine grinder effectiveness. Glen Mills is currently running grinder tests using zeolite beads.

\subsection{EVALUATION OF POTENTIAL OPTIONS}

During the survey and evaluation of equipment and processes for reduction of the $\mathrm{K}$ Basin sludge particle size, all vendor responses are the same in four general areas as follows:

1. To improve efficiency and reduce equipment wear and tear, only particles above $177 \mu \mathrm{m}$ should be process for size reduction.

2. Most of the surveyed equipment suppliers had no experience in the processing of metal uranium materials. Only the shredded type machine had been used on pre-irradiated fuel chips.

3. The efficiency of the reduction process is affected by the hardness values of the solid particulate in the sludge stream.

4. Testing of the reduction process would be required to verify that reduced particle size criteria could be achieved using a sludge simulant supplied by the SNF Project.

Evaluation of the process survey becomes difficult knowing that no equipment supplier has experience in processing post-irradiated uranium. proven technology for particle size reduction does exist for a wide range of other materials, but in this case, decisions based on past equipment performance with uranium can not be made.

To evaluate the equipment surveyed, a matrix (Table 1) is completed using the vendor/equipment type and a set of product criteria. The product criteria consists of items like product particle range, cost, reduced material types, production rates, wet/dry operation, maintenance/repair and others. A comment section is included where the decision and corresponding rationale to keep or remove the equipment/vendor from selection is recorded. 
Table 1. Comparison Matrix

\begin{tabular}{|c|c|c|c|c|c|c|c|c|c|}
\hline VENDOR & $\begin{array}{l}\text { PRODUCT } \\
\text { PARTICLE } \\
\text { RANGE }\end{array}$ & $\begin{array}{l}\text { COST/ } \\
\text { UNIT }\end{array}$ & $\begin{array}{l}\text { REDUCTION } \\
\text { MATERIAL }\end{array}$ & $\begin{array}{l}\text { PRODUCTION } \\
\text { RATE }\end{array}$ & $\begin{array}{l}\text { APPLICABLE } \\
\text { TECHNOLOGY }\end{array}$ & $\begin{array}{l}\text { WET/DRY } \\
\text { PROCESS }\end{array}$ & $\begin{array}{l}\text { SUBMERGED } \\
\text { OPERATION }\end{array}$ & REPAIR & COMMENTS \\
\hline \multicolumn{10}{|l|}{ HAMMER MIL $L$} \\
\hline Pulva Corp. & unknown & $\$ 50 \mathrm{~K}$ & Tungsten Carbide & Unknown & Xes & Wet/Dry & Unknown & Yes & Equipment available \\
\hline $\begin{array}{l}\text { Hosokawa Micron } \\
\text { Powder Systems }\end{array}$ & $177 \mu \mathrm{m}$ & $\$ 16-18 \mathrm{~K}$ & Carbide Steel & $45 \mathrm{ga} 1 / \mathrm{min}$ & No & Dry & No & Unknown & $\begin{array}{l}\text { Not recommended } \\
\text { by vendor }\end{array}$ \\
\hline \multicolumn{10}{|l|}{ GRINDER } \\
\hline Glenn Mills, Inc. & $\begin{aligned} 98 \% & <350 \mu \mathrm{m} \\
70 \% & <150 \mu \mathrm{m} \\
40 \% & <70 \mu \mathrm{m}\end{aligned}$ & $\$ 10 \mathrm{~K}$ & $\begin{array}{l}\text { Zirc Oxide and } \\
\text { Steel }\end{array}$ & $10-100 \mathrm{lb} / \mathrm{hr}$ & Yes & & & & \\
\hline $\begin{array}{l}\text { Glen Mills, Ine } \\
\text { (Toothed Disc Mill) }\end{array}$ & $300 \mu \mathrm{m}$ & $\$ 20 \mathrm{~K}$ & Unknown & $10-100 \mathrm{lb} / \mathrm{hr}$ & Yes & Wet/Dry & No & Yes & $\begin{array}{l}\text { Equipment available } \\
\text { - Tests required }\end{array}$ \\
\hline KA Works, Inc. & $\begin{array}{c}0 \%>3000 \mu \mathrm{m} \\
5 \%>200 \mu \mathrm{m} \\
20 \%>50 \mu \mathrm{m}\end{array}$ & $\$ 75-150 \mathrm{~K}$ & Zeolite & $75-100 \mathrm{gal} / \mathrm{min}$ & Yes & Wet & Unknown & Yes & $\begin{array}{l}\text { Equipment available } \\
\text { - Tests required }\end{array}$ \\
\hline \multicolumn{10}{|l|}{ SHREDDER } \\
\hline $\begin{array}{l}\text { Shrew Pax (Used in } \\
300 \text { Area) }\end{array}$ & $\begin{array}{l}0.25 \text { inch minimum } \\
\text { reduction }\end{array}$ & Unknown & Uranium & $\begin{array}{l}\text { Unknown (55 gal drums } \\
\text { of scrap fed into process) }\end{array}$ & Yes & Wet/Dry & Unknown & No & $\begin{array}{l}\text { Not recommended } \\
\text { due to particle range }\end{array}$ \\
\hline
\end{tabular}


HNF-SD-SNF-TI-051, Rev, 0

\subsection{RECOMMENDATION OF PREFERRED OPTION}

An existing particle size reduction process to reduce the particle size to less than 80 mesh ( $177 \mu \mathrm{m}$ diameter) could not be selected for the $\mathrm{K}$ Basin sludge. In all cases, the equipment suppliers could not commit to the $177 \mu \mathrm{m}$ diameter limit without testing to confirm the post-process size distribution results. This was mainly due to the lack of experience with the processing of metal uranium materials.

The survey did indicate that it may be feasible to use existing machines to reduce the $\mathrm{k}$ Basin sludge to the micron range with some particle size constraints. The following vendors are recommended as leading candidates for further consideration and testing.

Pulva Corp.

The Pulva Corp. hammer mill has been used to process tungsten carbide material and can handle various types of slurries, reducing the particles to micron size.

IKA Works, Inc. IKA Works, Inc. has experience at West Valley with grinding the feed material (Zeolite) to less than $40 \mu \mathrm{m}$ using a three stage high sheer machine.

Glen Mills, Inc. Glen Mills, Inc. is currently running tests at west valley using zeolite beads. No further information is available at present.

The most adaptable system that fits our needs, with regard to operation and cost efficiency, should be selected for testing. A sludge simulant needs to be selected to bound the $K$ Basin sludge properties (i.e., abrasiveness, hardness, brittleness, percent solids, density, etc.) and tested with the selected equipment. The test should generate data which can be used to correlate equipment wear as a function of sludge simulant used. The test should determine, within a reasonable probability, if the required size reduction is viable with the selected equipment.

It is recommended that testing be completed on suggested size reduction equipment to determine if the proposed TWRS particle size limit of less. than 80 mesh ( $177 \mu \mathrm{m}$ diameter) can be achieved. These tests should be performed to develop particle size constraints using a sludge simulant supplied by the SNF Projects.

To meet TWRS waste acceptance criteria, the $\mathrm{K}$ Basin sludge also requires chemical adjustment. It may be possible to combine chemical adjustment and the size reduction techniques described in this document to achieve the desired particle size. However, because there is no past experience reducing the materials that are expected in the $\mathrm{K}$ Basin sludge, test results could be a factor in negotiating a reasonably achievable particle size.

\subsection{REFERENCES}

Boston, H. L., 1997, Letter from Lockheed Martin Hanford Company to Duke Engineering and Services Hanford, 9750522, Particle Size Acceptance Criteria, dated February, , 1997, Richland, Washington.

Makenas, B. J., Welsh, T. I., Baker, R, B., Hanson, D. R., and Golcar, G. R., 1996, WHC-SP-1182, Analysis of Sludge from Hanford $K$ East Basin Floor and Weasel Pit, Westinghouse Hanford Company, Richland, Washington.

Konobeevsky, S.,T., et. al,, 1956, Effect of Irradiation of the Structure and Properties of Fissionable Materials, Proc. Intern. Conf. Peaceful Uses Atomic Energy, Geneva, 1955, 7, $433-440$, United Nations, New York. 
HNF-SD-SNE-TI-051， Rev. 0

Precechtel, D. R., 1996, Functional Design Criteria for the $K$ Basin Sludge Removal System, WHC-SD-SNF-FDC-004, Revision 0, Westinghouse Hanford Company, Richland, Washington.

Tipton, C. R. Jr., 1960, Reactor Handbook, Interstice Publishers, Inc., 250 Fifth Avenue, New York 1, New York. 


\section{DISTRIBUTION SHEET}

\begin{tabular}{|c|c|c|c|c|c|}
\hline \multirow{2}{*}{$\begin{array}{l}\text { To } \\
\text { Distribution }\end{array}$} & \multirow{2}{*}{\multicolumn{3}{|c|}{$\begin{array}{l}\text { From } \\
\text { Facility Upgrade Project }\end{array}$}} & \multicolumn{2}{|c|}{ Page 1 of 1} \\
\hline & & & & \multicolumn{2}{|c|}{ Date $03 / 11 / 97$} \\
\hline \multicolumn{4}{|l|}{ Project Title/Work Order } & \multicolumn{2}{|l|}{$\begin{array}{l}\text { EDT No. } \\
619695\end{array}$} \\
\hline \multicolumn{4}{|l|}{ Spent Nuclear Fuel Project } & ECN No. & N/A \\
\hline Name & MSIN & $\begin{array}{c}\text { Text } \\
\text { With } \\
\text { All } \\
\text { Attach. }\end{array}$ & $\begin{array}{l}\text { Text } \\
\text { Only }\end{array}$ & $\begin{array}{l}\text { Attach./ } \\
\text { Appendix } \\
\text { Only }\end{array}$ & $\begin{array}{l}\text { EDT/ECN } \\
\text { Only }\end{array}$ \\
\hline C. J. Alderman & \multicolumn{3}{|c|}{$\times 3-85$} & & \\
\hline K. D. Carothers & \multicolumn{3}{|c|}{ R1-51 } & & \\
\hline E. W. Gerber & \multicolumn{2}{|c|}{ R3-11 } & & & $\cdot$ \\
\hline B. A. Higley & \multicolumn{2}{|c|}{ H5-27 } & & & \\
\hline J. 0 Honeyman & \multicolumn{2}{|c|}{ G3-21 } & & & \\
\hline R. J. Lodwick & \multicolumn{2}{|c|}{$\times 3-78$} & & & \\
\hline G. R Mezger & \multicolumn{2}{|c|}{ S7-41 } & & & \\
\hline F. W. Moore & \multicolumn{2}{|c|}{$x 3-85$} & & & \\
\hline F. J. Muller & \multicolumn{2}{|c|}{$\times 3-85$} & & & \\
\hline M. J. Packer & \multicolumn{2}{|c|}{$x 3-85$} & & & \\
\hline I. G. Papp & \multicolumn{2}{|c|}{ H5-49 } & & & \\
\hline K. L. Pearce & \multicolumn{2}{|c|}{ R3-11 } & & & \\
\hline D. R. Precechtel & \multicolumn{2}{|c|}{$\times 3-85$} & & & \\
\hline J. P. STougter & \multicolumn{2}{|c|}{$R 2-54$} & & & \\
\hline D. H. Sp]ett & \multicolumn{2}{|c|}{$S 7-41$} & & & \\
\hline T. S. Vail & \multicolumn{2}{|c|}{$R 2-54$} & & & \\
\hline D. J. Washenfelder & \multicolumn{2}{|c|}{$57-40$} & & & \\
\hline M. J. Wiemers & \multicolumn{2}{|c|}{$x 3-85$} & & & \\
\hline SNF Project Files & \multicolumn{2}{|c|}{$x 3-85$} & & & \\
\hline
\end{tabular}

